\title{
SOSIALISASI CIRI-CIRI KEASLIAN UANG RUPIAH OLEH BANK INDONESIA KPW JAWA BARAT DALAM MENGURANGI PEREDARAN UANG PALSU DI PERBANKAN
}

\author{
Mellia Agustiyani, Hanny Hafiar, Evi Novianti \\ melliaaugust@gmail.com,hannyhafiar@gmail.com,evi.novianti@unpad.ac.id \\ Fakultas Ilmu Komunikasi, Universitas Padjadjaran
}

\begin{abstract}
ABSTRAK
Bank Indonesia merupakan lembaga independen yang mewajibkan untuk mensosialisasikan ciri keaslian uang rupiah atau sosialisasi CIKUR "Ciri-ciri Keaslian Uang Rupiah". Penelitian ini bertujuan untuk mengetahui fase dari model of small group socialization di Bank Indonesia KPw Jawa Barat. Metode yang digunakan adalah deskriptif dengan data kualitatif. Pengumpulan data penelitian dilakukan dengan cara observasi, wawancara dan studi literatur. Hasil penelitian menunjukan bahwa Asisten Manajer I Bank Indonesia KPw Jawa Barat yang berperan sebagai pengawas serta pelaksana sosialisasi CIKUR mulai dari fase pendahuluan, fase antisipasi, fase pertemuan, fase asimilasi, dan fase keluar. Pada fase pendahuluan, fase asimilasi, dan fase keluar, analisis demografi, identifikasi kelompok, evaluasi dan apresiasi yang dilakukan belum optimal. Dari hasil penelitian ini, saran yang diberikan adalah lembaga sebaiknya melakukan analisis demografi secara spesifik yaitu usia, ras dan gender, identifikasi kelompok evaluasi dan apresiasi agar tujuan utama sosialisasi dapat tercapai.
\end{abstract}

Kata Kunci : Fase, Sosialisasi, Model Sosialisasi Kelompok Kecil, Deskriptif, Kualitatif.

\section{ABSTRACT}

Bank Indonesia is an Independent institution which obligate to socialize characterized the authenticity of the rupiah or socialization CIKUR "characteristics of the authenticity of Rupiah". This study aims to determine The phase of the model of small group socialization process in Bank Indonesia KPw West Java. The method used is descriptive with qualitative data. The research data was collected by observation, interview and literature study. The results show that Assistant Manager I Bank Indonesia KPw West Java acts as an trustees and executors of socialization CIKUR from antecedent phase, anticipatory phase, encounter phase, assimilation phase, and exit phase. In the phase of antecedent, assimilation, and exit phase, demography analysis, group identification, evaluation and appreciation has not been optimal. From the results of this study, the suggestions provided are companies that do demographic analysis with specific age, race and sex, identification group, evaluation and appreciation so that the main goal of the socialization can be achieved.

Keywords : Phase, Socialization, Model of Small Group Socialization, Descriptive, Qualitative

\section{PENDAHULUAN}

Indonesia masih diresahkan dengan uang Rupiah palsu yang beredar di masyarakat. Dunia bisnis dan ekonomi yang beragam jenisnya memberikan peluang untuk mendapatkan keuntungan yang besar, dan ini dapat membuat manusia untuk menghalalkan segala cara demi mendapatkan keuntungan besar tersebut, salah satunya adalah melakukan kejahatan dengan media uang palsu.

Sosialisasi ciri-ciri keaslian uang rupiah (CIKUR) merupakan program untuk mengurangi dan meminimalisir peredaran 
uang palsu di masyarakat. Adanya sosialisasi ciri-ciri keaslian uang rupiah diharapkan dapat meminimalisir penyebaran uang palsu di masyarakat khususnya yang dilakukan oleh Divisi Sistem Pembayaran dan Pengelolaan Uang Rupiah, Bank Indonesia kantor perwakilan Jawa Barat. Setiap Bank Indo-nesia mengeluarkan uang emisi baru dan selama uang tersebut masih beredar dilakukan sosialisasi ke berbagai kalangan masyarakat khususnya yang berhubungan dengan keuang-an seperti perbankan, pasar swalayan, pelajar hingga masyarakat biasa.

Staf Kasir Junior Bank Indonesia KPw Jabar mengatakan bahwa penanganan uang palsu itu sendiri masih belum terkendali setiap tahunnya masih banyak data setiap daerah yang menunjukkan bahwa uang tersebut palsu. Salah satunya didapakan ari perbankan.

Berbicara mengenai sosialisasi maka tidak terlepas dari komunikasi dalam menyampaikan nilai tersebut, untuk melakukan sosialisasi yang berhasil maka perlu usaha untuk menentukan target sasaran peserta sosialisasi dan membangun identitas kelompok dalam sosialisasi salah satunya melalui pelaksanaan model of small group socialization.

Asisten Manajer Bank Indonesia mengatakan perbankan dipilih sebagai salah satu agen sosialisasi yang membantu Bank Indonesia dalam menyebarkan informasi mengenai keaslian ciri-ciri keaslian uang rupiah dalam hal menangani uang palsu, uang rusak, maupun yang berhubugan dengan fisik uang.

Diadakannya sosialisasi ciri-ciri keaslian uang rupiah pada perbankan karena setiap tahunnya terjadi pergantian pegawai, pegawai yang resign yang tak menentu dan ada beberapa perbankan khususnya di Jawa Barat yang belum pernah melaporkan uang palsunya. Maka dari itu perlu diadakannya sosialisasi CIKUR "Ciri-ciri Keaslian Uang Rupiah" khusus perbankan dalam menangani peredaran uang palsu di masyarakat.

Sosialisasi ciri keaslian uang rupiah yang dilakukan Bank Indonesia $\mathrm{KPw}$ Jawa Barat dalam mengurangi peredaran uang palsu diadakan dengan melakukan pengelompokan pada peserta sosialisasi yang berbeda-beda perbankan.

Menurut Dominicik yang dikutip oleh Effendy (1994: 31) nilai merupakan:

"suatu upaya transisi nilai-nilai (Trans-
mission of Values) yang mengacu kepada
cara-cara dimana sesesorang mengadopsi
perilaku serta nilai-nilai dari sebuah
kelompok".

Menjadikan komunikasi kelompok sebagai alat untuk mentransmisikan nilainilai ciri keaslian uang rupiah yang diantaranya mengenal uang asli dan palsu, cara penanganan uang palsu, uang rusak, dan informasi tambahan lainnya. Komunikasi kelompok menurur Arni (2011:182) :

"Komunikasi kelompok kecil (small group communication) merupakan komunikasi yang berlangsung secara tatap muka karena komunikator dan komunikan berada dalam situasi saling berhadapan dan saling melihat. Para anggotanya saling berinteraksi satu sama lain dan lebih intens."

Menurut Shaw ada enam cara untuk mengidentifikasikan suatu komunikasi kelompok kecil yaitu "suatu kumpulan individu yang dapat mempengaruhi satu sama lain, memperoleh beberapa kepuasan satu sama lain, berinteraksi untuk beberapa tujuan, mengambil peranan, terikat satu sama lain, dan berkomunikasi tatap muka." Maka, jika 
salah satu dari komponen itu hilang, individu yang terlibat tidaklah berkomunikasi dalam kelompok kecil.

Demi mewujudkan keberhasilan sosialisasi ciri-ciri keaslian uang rupiah, Divisi Sistem Pembayaran dan Pengelolaan Uang Rupiah di Bank Indonesia KPw Jawa Barat mengaktualisasikan sosialisasi melalui komunikasi kelompok kecil. Arni (2011: 182) mengatakan bahwa :

“(1) Pembuat keputusan. Orang-orang berkumpulbersama-sama dalam kelompok untuk membyuat keputusan mengenai sesuatu. Mendiskusikan alternatif dengan orang lain membantu orang memutuskan mana pilihan terbaik untuk kelompok. (2) Pemecah masalah. Kelompok kecil adalah cara yang terbaik untuk memecahkan masalah. Orang membentuk kelompok pemecah masalah dlam bermacammacam konteks seperti di tempat kerja, di pemerintah, di sekolah dan di rumah"

Pernyataan diatas membuktikan bahwa dengan dibuatnya kelompok kecil dan melaku-kan komunikasi di dalam kelompok akan menghasilkan keputusan dan pemecahan ma-salah bersama yang sedang dihadapi yaitu mengenai sosialisasi ciri-ciri keaslian uang rupiah untuk menekan jumlah peredaran uang palsu di perbankan.

Menurut Myers (2007: 29-34) langkahlangkah dalam mengelola sosialisasi yaitu fase pendahuluan (antecedent phase), fase antisipasi (anticipatory phase), fase pertemuan (encounter phase), fase asimilasi (assimilation phase), dan fase keluar (exit phase).

Kelima fase tersebut sudah dilakukan oleh Bank Indonesia KPw Jawa Barat. Staff divisi Sistem Pembayaran dan Pengelolaan Uang Rupiah mengatakan bahwa tujuan program sosialisasi ciri keaslian uang rupiah dengan melakukan komunikasi kelompok kecil di dalamnya yaitu untuk mengurangi peredaran uang palsu khususnya di perbankan.

Singkatnya, model sosialisasi kelompok kecil menggambarkan dalam lima tahap bagaimana anggota kelompok membawa kompetensi, sikap dan keyakinan untuk setiap kelompok yang mereka miliki (Anderson, 1999).

Proses sosialisasi mulai mengantisipasi kelompok dan anggota-anggotanya. Setelah anggota datang bersama-sama, interaksi yang komunikatif dan unik membantu mereka menetapkan aturan-aturan dasar dan normanorma dalam membangun identitas. Ketika anggota merasa nyaman dengan kelompok dan satu sama lain, mereka terlibat dalam fase asimilasi, yang mengikat dan membantu mereka memahami tugas mereka. Setelah selesai, anggota grup harus menghadapi hidup tanpa keanggotaan kelompok tersebut, dan ketika individu meninggalkan kelompok, mereka akan mempengaruhi bagaimana menghadapi hidup tanpa pengalaman kelompok tersebut. Bagian berikutnya mengeksplorasi hasil sosialisasi berhasil atau gagal.

\section{METODE PENELITIAN}

Metode yang digunakan dalam penelitian ini adalah deskriptif kualitatif. Menurut Whitney (1960) dalam Nazir (2011) menyebutkan bahwa:

"Deskriptif adalah pencarian fakta dengan interpretasi yang tepat. Deskriptif mempelajari masalah-masalah dalam mas-yarakat, serta tata cara yang berlaku dalam masyarakat serta situasi-situasi tertentu, termasuk tentang hubungan, kegiatan-kegiatan, sikap-sikap, pandangan-pandangan, serta proses yang 
sedang berlangsung dan berpengaruh dari suatu fenomena"

Pada penelitian deskriptif data yang dikumpulkan adalah berupa kata-kata, gambar dan bukan angka. Penelitian ini bersifat deskriptif karena pada penelitian ini berisi kutipan-kutipan data untuk memberikan gambaran penyajian laporan tersebut.

Data-data pada penelitian ini berasal dari naskah wawancara, cacatan lapangan, foto, dokumen pribadi, catatan atau memo, dan dokumen resmi lainya. Pada penelitian ini, dalam pelaksanaanya meliputi data, analisis dan interpretasi tentang arti dan data yang diperoleh.

Tujuan penelitian deskriptif menurut Nazir (2011: 54) mengatakan bahwa :

"Tujuan dari penelitian deskriptif ini adalah untuk membuat deskripsi, gambaran atau lukisan secara sistematis, faktual dan akurat mengenai fakta-fakta, sifat-sifat serta hubungan antara fenomena yang diselidiki."

Penelitian ini menggunakan studi deskriptif karena peneliti ingin mengetahui proses yang sedang berlangsung yaitu proses model of small group socialization dalam sosialisasi ciri-ciri keaslian uang rupiah oleh Bank Indonesia KPw Jawa Barat. Sosialisasi ini masih berlangusng hingga sekarang dan sudah dilakukan secara berkelanjutan sehingga dalam perspektif waktu penelitian deskriptif masih berlaku dimana responden masih dalam jangkauan ingatannya.

Paradigma yang digunakan dalam penelitian ini adalah paradigma positivisme. Menurut (Kincaid dalam Pawito, 2007: 49):

"Positivisme memandang sebuah realitas sebagai sesuatu yang bisa dipahami dan diasumsikan, yang dikendalikan oleh hukum. Paradigma positivisme merupakan paradigma yang identik dengan pola pikir deduktif."

Melalui penelitian ini, diketahui model of small group socialization yang dilakukan Bank Indonesia KPw Jawa Barat ini bukan hasil dari produknya. Peneliti di sini ingin mengamati model of small group socialization yang sedang terjadi di Bank Indonesia KPw Jawa Barat secara objektif dan berdasarkan konsep model of small group socialization.

Narasumber dalam penelitian ini adalah 1) Asisten Manajer Divisi Sistem Pembayaran dan Pengelolaan Uang Rupiah I; 2) Asisten Manajer Divisi Sistem Pembayaran dan Pengelolaan Uang Rupiah II; 3) Dua staff kasir junior divisi SP \& PUR; 4) Staff kasir senior divisi SP \& PUR; 5) Tiga peserta sosialisasi Ciri-ciri Keaslian Uang Rupiah (CIKUR).

Teknik pengumpulan data yang digunakan dalam penelitian ini terdiri dari 1) Wawancara. Wawancara ini dilakukan dengan terstruktur dan berulang-ulang secara intensif; Wawancara terstruktur adalah wawancara yang pewawancaranya menetapkan sendiri masalah dan pertanyaanpertanyaan yang akan diajukan.

2) Observasi Lapangan. Observasi lapangan atau pengamatan lapangan adalah program yang setiap saat dilakukan dengan kelengkapan panca indera yang dimiliki. Peneliti dalam observasi berperan pasif untuk meneliti sosialisasi CIKUR "Ciri-ciri Keaslian Uang Rupiah" oleh Bank Indonesia $\mathrm{KPw}$ Jawa Barat. Pada penelitian pasif ini peneliti tidak terlalu mendapatkan informasi yang mendalam.

3) Dokumentasi. Pengumpulan data 
ini melalui studi literatur terhadap buku dan artikel dari internet dan sebagainya yang berhubungan dengan kegiatan sosialisasi.

Teknik analisis data yang digunakan dalam penelitian ini adalah teknik analisis interaktif dari Miles dan Hubermas. Miles dan Hubermas 1994 dalam (Pawito, 2007: 105) menawarkan suatu teknik analisis yang lazim disebut dengan interactive model. Teknik analisis ini pada dasarnya terdiri dari tiga komponen yakni reduksi data (data reduction), penyajian data (data display), dan penarikan serta pengujian kesumpulan (drawing and verifying conclusions).

Triangulasi yang digunakan peneliti adalah triangulasi sumber, hal ini bertujuan agar dapat menghilangkan perbedaan-perbedaan konstruksi kenyataan yang ada dalam konteks suatu studi sewaktu mengumpulkan data tentang berbagai kejadian dan hubungan dari berbagai pandangan.

Menurut Patton dalam Moleong, 2009: $331)$.

"Triangulasi dengan sumber berarti membandingkan dan mengecek balik derajat kepercayaan suatu informasi yang diperoleh melalui waktu dan alat yang berbeda dalam penelitian kualitatif."

Dari beberapa sumber yang didapatkan data tersebut dideskripsikan, dikategorikan, mana pandangan yang sama, mana yang berbeda, dan mana yang spesifik dari beberapa sumber yang telah diwawancara.

\section{HASIL DAN PEMBAHASAN}

Fase pendahuluan (antecedent phase) yang Bank Indonesia KPw Jawa Barat dalam sosialisasi ciri-ciri keaslian uang rupiah terdapat analisis psikologi.
Asisten Manajer Bank Indonesia KPw Jawa Barat mengatakan dalam analisis psikologi dilakukan beberapa poin bahwa "melakukan door to door, klarifikasi dan setoran dengan begitu latar belakang, sikap, motivasi dan pengetahuan peserta sosialisasi mengenai ciri keaslian uang rupiah akan terlihat secara langsung maupun melalui data".

Langkah kedua dalam fase pendahuluan yaitu analisis demografi. Pengumpulan data yang dilakukan yaitu penetuan level, wilayah kerja dan survey. Penentuan level dan wilayah kerja dilakukan untuk penepatan sasaran peserta dan pemerataan daerah sosialisasi sesuai tingkat peredaran uang palsu dan wilayah kerja Bank Indonesia KPw Jawa Barat.

Survey yang dilakukan dalam menentukan peserta sosialisasi CIKUR tidak dikelompokan berdasarkan usia, ras dan jenis kelamin, sehingga survey dilakukan hanya berdasarkan pemahaman para teller masingmasing perbankan.

Dari data survey masih ditemukan peserta yang bukan dari bagian teller yang dikhususkan dan berhubungan langsung dengan fisik uang, dari segi usia masih variatif baik itu fresh graduate, maupun yang sudah senior, lalu peserta dengan berbagai macam ras/suku bermacam-macam.

Setelah rangkaian fase pendahuluan untuk ditentukan target sasaran peserta sosialisasi kemudian dilakukan fase antisipasi. Peserta menyatakan harapan individu dan harapan kelompok. Beberapa individu mengungkapkan harapan diantaranya mengenal teman kelom-pok satu sama lain dan untuk mempunyai pengalaman mendapatkan materi CIKUR (Ciri-ciri Keaslian Uang Rupiah) langsung dari Bank Indonesia. 
Kemudian harapan kelompok disebutkan bahwa mereka ingin paham dengan materi ciri keaslian uang rupiah dan menerpkan nilai tersebut di perbankan masing-masing. Dari kedua sisi tersebut adanya kesamaan harapan agar tercapainya tujuan dari sosialisasi ciriciri keasian uang rupiah atau CIKUR.

Fase pertemuan model of small group socialization oleh Bank Indonesia dalam mengurangi peredaran uang palsu di perbankan adalah sebagai berikut, Perbankan berada di target level dua sosialisasi dilakukan secara face-to-face berbentuk seminar, sebelum dilakukan sosialisasi, Bank Indonesia menyebarkan undangan melalui media surat kepada perbankan. Pada saat sosialisasi berlangsung materi disampaikan menggunakan media cetak seperti modul, juga menggunakan media elektronik seperti power point, video/ film pendek.

Kelompok mulai menetapkan tujuan, dilakukan dengan cara diskusi yang hasilnya bertukar informasi mengenai ciri keaslian uang rupiah dan cara penanganan uang palsu di tiap berbankan beserta penerapannya. Setelah ditetapkan tujuan tersebut disesuaikan dengan cara menjalankan peran pada saat penugasan.

Setelah tujuan ditetapkan dan disesuaikan, kelompok mulai membangun peran, peran kelompok dilakukan dengan baik sesuai dengan tujuan kelompok, hal ini terbukti pada saat penugasan yang diberikan oleh Bank Indonesia salah satunya membedakan uang asli dan palsu, dalam fase ini tiap individu berperan sebagai pengikut saja.

Memberikan penugasan dilakukan dengan mempraktekan apa yang sudah dipaparkan pada power point dan diperagakan oleh petugas. Peserta menjalankan tugasnya sesuai dengan tujuan dan mengevaluasi kemampuan individu masing-masing.

Dari hasil penelitian ini dapat diketahui bahwa dalam fase pertemuan terdapat kendala yaitu tidak adanya pembagian peran individu dalam tiap kelompoknya.

Fase asimilasi model of small group socialization oleh Bank Indonesia KPw Jawa Barat sebagai berikut. Langkah pertama dalam fase ini anggota mengadopsi budaya/ nilai baru, penerapan nilai tersebut dilakukan pada saat sosialisasi namun setelah memasuki lingkungan kerja belum dilakukan secara maksimal. Hal ini dilihat melalui penugasan dan data klarifikasi tiap perbankan.

Penerapan nilai/budaya tersebut disamakan dengan kelompok melalui diskusi dan penugasan, dalam hal ini peserta maupun kelompoknya dinilai secara langsung. Untuk membangun hubungan antar peserta Bank Indonesia melakukan pengelompokkan, satu kelompok terdiri dari beberapa perbankan namun dalam hal ini pendekatan lebih fokus dalam membangun hubungan secara personal dibandingkan membangun hubungan pekerjaan.

Identitas kelompok dilakukan dengan menentukan tujuan kelompok yaitu ingin paham dan menerapkan nilai tersebut di perbankan masing-masing, kemudian prinsip individu, tiap individu lebih membangun identitas diri dibandingkan kelompok sehingga identitas kelompok tidak tercapai dengan maksimal.

Fase keluar model of small group socialization oleh Bank Indonesia $\mathrm{KPw}$ Jabar adalah sebagai berikut. Evaluasi menjadi tolak ukur keberhasilan sosialisasi, Bank Indonesia melakukan post and pretest dengan menyebarkan quisioner namun evaluasi ini hanya dilakukan pada saat 
uang emisi baru keluar dan selebihnya jarang dilakukan. Sesungguhnya, evaluasi program tergantung pada programnya. Sebab, mengacu pada hasil riset "tak jarang bila dalam pelaksanaan program terdapat hambatan dan halangan yang mengharuskan untuk melakukan aktivitas di luar rencana, disesuaikan dengan kebutuhan dan berjalan secara spontan (Nassaluka, Hafiar, \& Priyatna, 2016).

Kedua yaitu apresiasi, dilakukan berbarengan dengan acara gathering bersama perbankan setahun sekali dengan memberikan award yang dihadiri pimpinan direksi. Dan yang terakhir individu leave-taking effect. Peserta sosialisasi belum mengeksplorasi informasi yang telah didapat, hal ini dianggap mempengaruhi pemerataan pesan ketika individu kembali ke lingkungan kerja masing-masing.

Pada fase pendahuluan terdapat tahap yang belum maksimal yakni analisis demografi, survey dalam klasifikasi ras, usia, dan gender belum dilakukan secara spesifik, sebaiknya hal ini dilakukan agar peserta memiliki latar belakang yang sama sehingga pemahaman peserta dipahami secara rata. Sebab, menurut Mulyana, (2006: 23), anggota masyarakat berbagi persepsi dasar mengenai dunia yang mereka internalisasikan melalui sosialisasi dan memungkinkan mereka melakukan interaksi atau komunikasi (Nurtyasrini \& Hafiar, 2016).

Sedangkan, pengelompokan perlu dilakukan untuk mendapatkan sasaran yang tepat dan informasi/pesan diserap secara merata. Menurut (Myers, 2007: 31) :

"The first phase is the antecedent phase. In the case study, some members expressed beliefs and attitudes, both positive and negative, about group work based on personal experiences or experiences shared by others. Researchers seem agree that whether you're entering an existing group or new group matters not; what you bring to a group -beliefs, attitudes, and communicative and personality traitswill influence the group's culture and members"

Bank Indonesia KPw Jawa Barat seharusnya mengoptimalkan analisis demografi dengan cara melakukan analisis target peserta secara detail. Seperti yang dikatakan oleh Kohlberg, (1958) dalam William (2007, 109):

"Usia memiliki peran dalam perkembangan moral kognitif. Kohlberg menyatakan mela-lui enam langkahlangkah progresif, suatu pertimbangan etis seseorang berkembang dari level pre-conventional sampai level postconventional. Namun, beberapa studi empiris menemukan bahwa orang-orang muda membuat penilaian etis yang lebih baik daripada orang yang lebih tua"

Kemudian menurut Betz (1989:321) menjelaskan bahwa:

"Pendekatan sosialisasi gender laki-laki dan perempuan membawa norma dan nilai yang berbeda dimana tempat mereka bekerja, yang menyebabkan adanya perbe-daan tersebut dilandaskan pada gender antara laki-laki dan perempuan dalam membentuk kepentingan karier, keputusan serta penerapannya."

Berdasarkan hal tersebut sebaiknya Bank Indonesia KPw Jabar melakukan pengelompokan secara detail mengenai usia, ras, dan gender dalam menentukan target peserta sosialisasi.

Fase kedua dalam model of small group socialization yaitu fase antisipasi, hal ini sudah sesuai dengan konsep model 
of small group Socialization karena adanya kesesuaian antara harapan individu dan harapan kelompok, namun, perlu ditingkatkan kembali. Myers (2007: 31) mengatakan :

"The second phase is the anticipatory phase, in which individuals decides what they expect from group membership as well as each group member. At the group level, existing groups from expectations about new group members. Equally, members of a zero history group"

Pengaruh besarnya harapan individu terhadap individu lain akan terlihat pada saat sosialisasi berlangsung contohnya dari cara anggota berinteraksi satu sama lain. Dengan keanggotaan kelompok yang bertujuan sama akan menciptakan suasana lingkungan yang harmonis yang nantinya berdampak pada keberhasilan sosialisasi. Sebaiknya dilakukan dinamika kelompok agar menghasilkan kerja-sama kelompok yang optimal. Menurut (Munir, 2001: 23) :

"Sebagai metoda, dinamika kelompok, membuat setiap anggota kelompok semakin menyadari siapa dirinya dan siapa orang lain yang hadir bersamanya dalam kelompok dengan segala kelebihan dan kekurangannya masing-masing. Kesadaran semacam ini perlu diciptakan karena kelompok atau organisasi akan menjadi efektif apabila memiliki satu tujuan, satu cara tertentu untuk mencapai tujuan yang diciptakan dan disepakati bersama dengan melibatkan semua individu anggota kelompok tersebut sesuai dengan kemampuannya masing-masing."

Dengan melakukan dinamika kelompok diharapkan adanya kesesuaian antara harapan individu dan kelompok, tugas dan anggota akan berpengaruh keberhasilan sosialisasi.
Fase ketiga yakni fase pertemuan, pertemuan dilakukan secara face-to-face menggunakan media cetak seperti modul dan media lainnya seperti power point dan film pendek/video. Untuk mengundang peserta Bank Indonesia KPw Jabar menggunakan media cetak surat sebagai undangan.

Sebaiknya pengelola sosialisasi dapat menginformasikan kegiatan lebih optimal dengancaramenggunakansalurankomunikasi personal untuk menginformasikan kegiatan sosialisasi. Karena saluran komunikasi personal baik yang bersifat langsung melalui perseorangan atau melalui kelompok, lebih persuasif dibandingkan dengan saluran media massa. Sehingga partisipasi kegiatan akan lebih tepat sasaran jika menggunakan saluran komunikasi personal. Misalnya surat ditujukkan kepada head teller perbankan yang akan diundang. Menurut (Effendi, 2009: 212):

“...saluran komunikasi personal lebih efektif untuk menyampaikan pesan pada perseorangan. hal ini karena disebabkan faktor sebagai berikut: (1) Penyampaian pesan melalui saluran komunikasi personal dapat dilakukan secara langsung kepada khalayak yang dituju, bersifat manusiawi dan pribadi. (2) Penyampaian pesan melalui saluran komunikasi personal dapat dilakukan lebih terperinci dan lebih fleksibel disesuaikan dengan situasi dan kondisi nyata. (3) Keterlibatan khalayak dalam proses komunikasi cukup tinggi..."

Intinya, Kesiapan pendokumentasian pada dasarnya adalah scientific communication (komunikasi ilmiah) dengan kegiatan mencari melalui analisis kebutuhan, penyampaian, pengolahan, pengorganisasian, penyebaran dan menyalurkan informasi (knowledge) kepada penggunanya (Rohanda, 
2013). Oleh karena itu tahap kedua pada fase ini yaitu proses pembentukkan tujuan kelompok yang mana sudah sesuai dengan konsep model of small group socialization yaitu ingin saling mengenal satu sama lain kemudian memenuhi kewajibannya ditugaskan perbankannya masing-masing untuk menghadiri sosialisasi ciri keaslian uang rupiah dengan begitu individu bisa lebih paham dan mendapatkan pengalaman baru dari sosialisasi ini. Menurut (Myers, 2007: 31):

"In additional, establishing roles and orienting members to their roles factor into the encounter phase. It is important to establish one critical activity in this phase: the adjustment and accommodation between individual members and the group over desirable role choices and the appropriate role behaviors."

Setelah rangkaian proses pembentukan tujuan kelompok sudah sesuai, fase pertemuan selanjutnya adalah penyesuaian tujuan kelompok. Tujuan kelompok terlihat pada saat individu membentuk peran nya melalui penugasan yang diberikan Bank Indonesia KPw Jawa Barat. Peran yang dijalankan peserta sebagai pengikut dan pemateri sebagai pemandu (leader).

Jadiperanberfungsiuntukmembedakan anggota kelompok berdasarkan tanggung jawab masing-masing. Peran juga membantu menciptakan lingkungan yang stabil serta peran dapat mempengaruhi tingkah laku individu. Benne dan Sheats (dalam Forsyth, 1983) membagi peran sebagai berikut:

"(1) Task role: anggota kelompok yang melakukan tugasnya untuk mencapai tujuan tertentu pada kelompok tersebut. Misalnya sebagai coordinator, elaborator, energizer, evaluatorcritic, information giver, infor-mation seeker, dan opinion seeker. (2) Sociemotional role: Posisi anggota dalam kelompok untuk mendukung perilaku inter-personal secara akomodatif. Misalnya compromiser, encourager, follower, dan harmonizer. (3) Individual role: peran individu yang tidak berkontribusi dengan besar, namun tetap dibutuhkan perannya sebagai penopang kebutuhan kelompok. Misalnya aggressor, block, dominator, dan help seeker."

Sebaiknya kelompok dalam sosialisasi ciri keaslian uang rupiah membagi perannya ketika penugasan agar individu mempunyai perannya masing-masing.

Fase keempat dalam model of small socialization yaitu menyesuaikan dengan penerimaan budaya/nilai anggota kemudian nilai tersebut disesuaikan dengan kelompok agar terjalin hubungan antar peserta maupun kelompok sehingga terakhir terbentuk identitas kelompok, semua tahap tersebut sudah dilakukan namun belum optimal.

Pada saat sosialisasi CIKUR "Ciri-ciri Keaslian Uang Rupiah” peserta menerima budaya tersebut dibuktikan pada saat penugasan atau praktek yang diberikan Bank Indonesia, peserta menjadi lebih aktif dalam bertukar informasi maupun mempraktekan dengan sesama anggotanya dengan melakukan pendekatan secara pribadi. Swogger dalam (Myers, 2007: 32) :

In the fourth phase, the assimilation phase, new members accept the established group culture and begin to identify with the group and its members. As applied to groups, culture encompasses members creating a unique group and using communicative behaviors exclusive to their group to make sense of what they do (swogger, 1981.)

Salah satu peserta sosialisasi ciri keaslian uang rupiah mengatakan mengatakan 
bahwa pada saat sosialisasi peserta maupun kelompok menerima nilai dan budaya tersebut dengan menlakukan komunikasi interpersonal dengan tiap anggota tetapi dalam menerapkannya di tiap perbankan itu tergantung kebiasaan dan budaya masingmasing individu maupun perbankan.

Untuk menyukseskan fase asimilasi ini salah satunya membangun hubungan dengan antar anggota kelompok, langkah ketiga ini sudah sesuai dengan model of small group socialization process. Salah satu faktor berhasilnya membangun hubungan ini yaitu dengan dibuatnya kelompok-kelompok kecil.

Langkah terakhir dalam fase asimilasi yaitu membentuk identitas kelompok mengacu pada tujuan kelompok dan prinsipindividu. Dalam penentuan prinsip individu yang dilakukan anggota kelompok kurang sesuai dengan model of small group socialization karena prinsip anggota berpacu pada masingmasing perbankan misalnya cara penanganan uang palsu, salah satu anggota menjelaskan bahwa ia hanya menerima uang palsu jika nasabah atau masyarakat tersebut sengaja menyetorkan uang palsu tersebut berbedajika ada nasabah yang menyetorkan uangnya lalu terselip uang palsu, ia akan mengembalikan uang tersebut. Hal ini dapat disimpulkan bahwa tujuan dan prinsip kelompok belum dilakukan secara maksimal dan tidak semua anggota langsung menerapkan hal tersebut di tempatnya masing-masing. Barker (2009: 221) mengatakan :

"identitas adalah persamaan dan perbedaan, soal personal dan soal sosial, apa yang kita miliki secara bersama-sama dengan beberapa orang dan apa yang membedakan kita dari orang lain. identitas akan mencirikan sebuah kelompok dan menjelaskan keunikan kelompok dengan kelompok yang lain."
Kemudian Tajfel \& Turner dalam Haslam (2001: 60) mengatakan :

"Dalam pembentukkan identitas kelompok juga terdapat proses pembentukkan yang didasari oleh identitas yang dimiliki anggotanya. Proses pembentukkan identitas melalui tiga tahapan yaitu kategorisasi, identifikasi, perbandingan sosial sebagai berikut: (1) Kategorisasi (categorization). Individu mengenali dan mengelompokkan identitas-identitas berdasarkan kategori sosial seperti etnis, ras, religi, pekerjaan, status sosial dan sebagainya. (2) Identifikasi (Identification). Pada tahap ini individu mengidentifikasikan dirinya terhadap kelompok-kelompok tertentu dimana ia terafiliasi. Dalam identifikasi terkandung dua makna dalam diri individu, pertama, bahwa sebagian dari individu dibangun berdasarkan keanggotaan dalam suatu kelompok. Dalam hal ini terdapat pemikiran kamu vs mereka. Kedua, bahwa pada saat tertentu individu berfikir bahwa dirinya sebagai aku, dan memandang dirinya sebagai anggota suatu kelompok, yang disebut sebagai social identity, dan pada saat yang lain memandang dirinya sebagai individu yang unik, yang disebut sebagai personal identity. (3) Perbandingan sosial. Tindakan individu yang membuat perbandingan antara dirinya dengan orang laindalam rangka mengevaluasi dirinya."

Sebaiknya kategorisasi dilakukan diawali dengan kategorisasi ras, etnis, agama, religi dan status sosial kemudian proses identifikasi tidak dilakukan secara maksimal, dalam artian antar anggota atau individu menganggap dirinya mempunyai prinsip masing-masing sehingga komunikasi yang unik dari kelompok tersebut tidak menonjol secara maksimal.

Fase kelima dalam model of small group socialization yaitu evaluasi, apresiasi 
dan individu-leave taking effect. Evaluasi dilakukan berupa post and pre test dalam bentuk quisioner yang disebarkan sebelum dan sesudah sosialisasi, selebihnya Bank Indonesia tidak melakukan evaluasi terhadap individu maupun kelompok peserta sosialisasi ciri keaslian uang rupiah. Lester dan Stewart (2000: 132) menyebutkan dua hal penilaian dalam evaluasi pada kebijakan yang sudah berjalan, yaitu:

“(1) Penilaian terhadap hasil (outcome), dapat juga dikatakan evaluasi kinerja. Evaluasi ini dilakukan untuk kegiatan yang telah berjalan. Karena sifatnya hanya bisa dilakukan untuk kegiatan yang telah berjalan maka hasil dari evaluasi outcome dapat digunakan untuk penyempurnaan kegiatan selanjutnya. (2) Penilaian terhadap dampak (impact), evaluasi ini lebih fokus terhadap output atau dampak dibandingkan pada prosesnya. Dapat dikatakan untuk menilai hasil, atau target jangka panjang dari kebijakan."

Sebaiknya Bank Indonesia KPw Jabar lebih mengoptimalkan evaluasi agar program terlaksana dengan tujuan dan target yang tepat, kemudian evaluasi juga bisa menjadi metode analisis jika adanya suatu kendala saat pelaksanaan program/kegiatan.

Setelah melakukan evaluasi dilanjutkan dengan mengapresiasi hasil kerja peserta yang mana peserta sudah diberikan materi dan juga penugasan apa yang sudah dipaparkan oleh pemateri. Apresiasi yang diberikan Bank Indonesia hanya dilakukan satu tahun sekali berbarengan dengan gathering bersama perbankan, gathering tersebut berisi rangkaian silaturahmi dan pemberian award, gathering tersebut dihadiri oleh pimpinan cabang perbankan saja. Sutrisno (2009: 167):

"Membagi faktor bidang dalam penilaian prestasi dalam beberapa bagian antara lain: (1) Pengetahuan pekerjaan: tingkat pengetahuan yang terkait dengan tugas pekerjaan yang akan berpengaruh langsung terhadap kuantitas dan kualitas kerja. (2) inisiatif: tingkat inisiatif selama melaksanakan tugas pekerjaan khususnya dalam hal penanganan masalah-masalah yang timbul. (3) Kecekatan mental: tingkat kemampuan dan kecepatan dalam menerima instruksi kerja dan menyesuaikan dengan cara kerja serta situasi kerja yang ada. (4) Sikap: Tingkat semangat kerja serta sikap positif dalam dalam melaksanakan tugas pekerjaan."

Sebaiknya setiap sosialisasi ciri keaslian uang rupiah berlangsung Bank Indonesia Bank Indonesia KPw Jabar melakukan apresiasi, dengan diadakannya penilaian/ apresiasi kerja peserta bisa termotivasi akan hasil yang telah dilakukan.

Tahap terakhir dalam fase keluar yakni individual leave-taking effect karena individu dianggap mempengaruhi sikap tentang masa depan kelompok dan perilaku mereka. Ini merupakan salah satu tujuan dari Bank Indonesia KPw Jabar yaitu menjadikan perbankan sebagai agen sosialisasi minimal untuk dirinya sendiri maupun kelompoknya di masing-masing perbankan. Individual leave-taking effect yang dilakukan peserta sosialisasi ciri keaslian uang rupiah belum optimal perlu adanya kesadaran yang lebih akan hal tersebut. Robert Bonnington, (1973) dalam Sendjaja (1994: 64) menyatakan fungsi komunikasi dalam organisasi/kelompok adalah sebagai berikut:

\footnotetext{
"Organisasi/kelompok dapat dipandang sebagai suatu sistem pemrosesan informasi. Artinya, seluruh anggota dalam suatu organisasi berharap dapat memperoleh informasi yang lebih banyak, lebih baik dan tepat waktu. Informasi yang didapat memungkinkan setiap anggota organisasi
} 
dapat melaksanakan pekerjaannya secara lebih pasti."

Dari hasil temuan tersebut sebaiknya peserta sosialisasi ciri keaslian uang rupiah melakukan fungsi informatif setelah memasuki lingkungan kerja atau perbankan masing-masing, agar informasi yang didapat saat sosialisasi dapat di share kembali dan disebarluaskan secara merata.

\section{SIMPULAN}

1. Fase pendahuluan (antecedent phase) model of small group socialization oleh Bank Indonesia KPw Jabar meliputi analisis situasi psikologi dan demografi. Pada analisis psikologi Bank Indonesia melakukan door to door, dari door to door Bank Indonesia dapat mengetahui karakteristik perbankan, respon negatif atau positif mengenai penanganan uang palsu, dan nilai yang dianut perusahaan. Kemudian data klarifikasi dan setoran. Namun, dalam penentuan demografis peserta khususnya yang dilakukan dengan survey belum secara spesifik, masih ada peserta yang bukan dari bagian teller yang dikhususkan dan berhubungan langsung dengan fisik uang. Kemudian dari segi usia masih variatif, dan yang terakhir penentuan daerah peserta sosialisasi sudah sesuai karena berdasarkan level, dan sesuai dengan wilayah kerja Bank Indonesia KPw Jabar.

2. Fase antisipasi (anticipatory phase) model of small group socialization oleh Bank Indonesia KPw Jabar meliputi harapan individu dan harapan kelompok. harapan individu yang menyatakan bahwa ingin mengenal peserta maupun anggotanya satu sama lain kemudian menjadikan sosialisasi CIKUR ini pengalaman tersendiri bagi peserta karena diberi materi langsung oleh Bank Indonesia. Kemudian harapan kelompok diantaranya ingin paham paham akan materi ciri keaslian uang rupiah dan informasi terkait mata uang lainnya sekaligus berusaha menerapkan nilainilai tersebut di masing-masing cabang perbankan.

3. Fase pertemuan (encounter phase) model of small group socialization oleh Bank Indonesia KPw Jabar meliputi menentukan pertemuan menggunakan media maupun secara langsung dalam melaksanakan sosialisasi CIKUR. Bank Indonesia menggunakan media cetak surat untuk menyebarkan undangan. Sosialisasi dilaksanakan secara langsung atau face-to-face dengan menggunakan materi melalui media cetak berupa modul, power point dan video/film pendek mengenai ciri keaslian uang rupiah maupun cara penanganannya dan UU mengenai mata uang. Kedua membentuk tujuan melalui kelompok diskusi yang bertujuan menciptakan kondisi yang komunikatif antar peserta agar terjadi pertukaran informasi, kemudian tujuan tersebut dibuktikan dengan menjalankan peran pada saat penugasan atau praktek yang diberikan oleh Bank Indonesia.

4. Fase asimilasi (Assimilation phase) model of small group socialization yang dilakukan Bank Indonesia meliputi anggota mengadopsi budaya/nilai yang diberikan Bank Indonesia. Hal ini sudah sesuai karena peserta menjalankan perannya dengan baik dan paham akan isi 
materi CIKUR, melalui data survey dan klarifikasi. Kedua anggota menyamakan nilai-nilai tersebut dengan cara diskusi dan penugasan yang diberikan. Ketiga individu menjalin hubungan salah satunya dibuat kelompok dan satu kelompok tersebut terdiri dari beberapa cabang perbankan. Dengan membentuk kelompok akan terjadi komunikasi sehingga terjalin hubungan satu sama lain

5. Fase keluar (exit phase) model of small group socialization yang dilakukan oleh Bank Indonesia meliputi evaluasi hal ini sudah dilakukan namun belum optimal, Bank Indonesia KPw Jabar hanya melakukan evaluasi pada saat emisi uang baru keluar, selebihnya tidak dilakukan, evaluasi dilakukan melalui post dan pre test dengan cara menyebar quisioner sebelum dan sesudah sosialisasi. Kedua Bank Indonesia melakukan apresiasi namun belum optimal hal ini karena apresiasi hanya dilakukan satu tahun sekali sekaligus gathering bersama perbankan, selebihnya Bank Indonesia tidak melakukan apresiasi di setiap sosialisasinya. Dan yang terakhir individu leave-taking effect dimana individu mempengaruhi kelompoknya setelah dilakukannya sosialisasi ciri keaslian uang rupiah. Peserta belum mengeksplorasi informasi yang sudah didapat selama sosialisasi kemudian informasi/pesan yang sudah didapat kurang disampaikan dengan maksimal pada lingkungan kerjanya masingmasing. pesan yang disampaikan tidak merata dan hanya didapatkan oleh dua orang perwakilan saja.

\section{DAFTAR PUSTAKA}

Arni, Muhammad. 2011. Komunikasi Organisasi. Jakarta: Bumi Aksara

Barker, Chris. 2009. Cultural Studies, Teori dan Praktik, Jogjakarta: Kreasi Wacana

Betz, M. O. 1989. 'Gender Differences in Proclivity for Unethical', Vol. 8. Journal of Business Ethics , pp. 321-324

Crain, William. 2007. Theories of Development, Concepts and Applications (third ed.). Trans. Yudi Santoso. Yogyakarta: Penerbit Pustaka Pelajar.

Effendy, Onong Uchjana. 2003. Ilmu, Teori Dan Filsafat Komunikasi. Bandung: Citra Aditya Bakti.

Forsyth, D.R. 1983. An introduction to group dynamics. California: Brooks/Cole Publishing Company

Haslam, S Alexander. 2001. Phsychology in Organizations. London: SAGE Publications Ltd

Moh Nazir. 2011. Metode Penelitian. Cetakan 6. Bogor: Penerbit Ghalia Indonesia

Moleong, Lexy, J. 2009. Metode Penelitian Kualitatif. Bandung: Rosdakarya

Munir, B. 2001. Dinamika Kelompok, Penerapannya dalam Laboratorium Ilmu Perilaku. Jakarta: Universitas Sriwijaya.

Myers. 2007. Chapter 2: The Small Group Socialization Process. P.31-34

Nassaluka, E. U. R., Hafiar, H., \& Priyatna, C. C. (2016). Model Kemitraan PT. Holcim Indonesia Tbk. Jurnal Profesi Humas, 1(1), 22-34.

Nurtyasrini, S., \& Hafiar, H. (2016). Pengalaman Komunikasi Pemulung Tentang Pemeliharaan Kesehatan Diri Dan Lingkungan Di TPA Bantar Gebang. Jurnal Kajian Komunikasi, 
Pawito. 2007. Penelitian Komunikasi Kualitatif. Yogyakarta. PT Lkis

Rohanda, R. (2013). Landasan Ilmiah Ilmu Informasi Perpustakaan dalam Perspektif Ilmu Komunikasi. Jurnal Kajian Informasi \& Perpustakaan, 1(1), 9-20.
Sendjaja, S Djuarsa. 1994. Teori Komunikasi. Pusat Penerbitan Universitas Terbuka.

Sutrisno, Edi. 2009. Manajemen Sumber Daya Manusia Edisi pertama. Jakarta: Kencana Prenada Media Group 